\title{
町村氏の書評に応える
}

\section{倉沢 進}

私たちの『新編東京圈の社会地図 1975 - 90』の評者に町村敬志氏を得たことは、あり がたいことであった。同氏と編集委員会の労に感謝申し上げる。

\section{1 基層問題}

始めに町村氏が正面から採りあげなかった、そして筆者がもっとも重要な研究の動機な いし貢献と思っているポイントについて、ごく簡単に触れておきたい。

それは都市社会の構造と変動、とくに空間構造の変動に、最重要な影響を与える動因は 何かの問題である。多くの論者は、政治的な決定や、制度変革、巨大な開発プロジェクト などにそれを求める。もっとも典型的なのは国家独占資本論のように、政治・行政・産業 界が一つの統合本部を持ち、一切を組織的に企画実行し、その目的通りの結果がもたらさ れ、これに市民・住民は暴力的に支配されるという構図である。町村氏のよって立つ世界 都市論も、ほぼこれに近い視座を持つもののように考えられる。

筆者は、統合本部は幻想と考え、政治・行政・産業界はそれぞれの論理と利害に基づい て、しばしば協力し、また対立抗争しつつ、アクションが進行するものと考える。そして 一層重要なことは、その基層である。市民一人一人が、時にはこれに適応し、時には抵抗 しつつ、それぞれの利害に基づいて行動する、もう一方のアクターであると考える。一人 一人の市民は、多くの選択肢を持つ富裕層から、選択の幅が極度に狭い貧困層まで、その ライフスタイルや価值観にもとづいて、立地選択行動をする。我々が作りあげた地図は、 このような無数の市民の行動軌跡の、いわば積分值を示していると考えられる。

立地選択ではないが、一つの例を挙げよう。昭和 30 年に始まる公団住宅の建設は、都 市住宅のあり方を大きく左右する巨大事業であった。専門家たちの理想は、2 D K という 住宅基準に集約される。2寝室ということは就寝分離つまり親夫婦と子供達は寝室を別に するという理念、D K は食寝分離つまり寝室とちやぶ台の分離という理念であった。多く の入居者はこの公団住宅に基本的には適応しつつ、ある部分で反逆した。D K に接した畳 
の寝室に、ソファ応接セットをおき、居間として使ったのである。就寝分離を犠牲にして も居間空間を大切に考えた多くの住民の行動は、やがて生活水準・居住水準の向上と共 に、n L D K という住居様式を、行政や住宅産業界に受け入れさせたのであった。

このような我々の基層認識、都市空間が政・官・産の巨大な力と、これに適応・抵抗す る市民の行動の相互作用によって形作られているという認識は、我々の変数選択となって 表れている。舌足らずであるがこのことを一言述べ、町村氏のこの基本認識に対する見解 を将来承ることを願って、以下には氏の論点についてお答えをしょうと思う。

\section{2 地図化の〈落とし穴〉}

町村氏は地図化について、次のようなコメントをしている。ＧＩＳの活用が容易になる につれて、膨大なデータを加工したマッピングの試みを目にする機会が最近増えている。 しかし半ば思いつきで作られた多くの地図…出会い、うんざりした経験があるのは評者 だけではないだろう。本書にいたるこのグループの一連の仕事は、シカゴ学派以来の系譜 を受け継ぐ古典的な成果であると同時に、こうした空間分析の先駆けという位置にある。 だがそれだけに、本書もまた同じような陳腐化の危険性に直面している可能性がある。一 目瞭然のパターン発見には確かにある種の快感が伴う。しかしこの〈快感〉が〈思考停止〉 とつながりやすい所に、マッピングの〈落とし穴〉がある。」

地困化という手法は、ある空間についての無限に豊かな現実/情報の中から、特定の情 報に注目し記号化して、地図という限られた平面上に標示する手続きである。その地図化 が適切であるかは、その地図作成の目的と、その手続きないし作製された地図との整合性 如何による。等高線の標示を中心とした地形図は、登山者には役立つが、郵便配達には何 の役にも立たないし、地下鉄網図は、極端なデフォルメがなされていて、距離・方位など 地形図では最重要の要素については無関心である。すべての目的に合致した地図は存在し ないし、良い地図か否かは、その地図が強調しょうとする目的にどれほど合致し、それに 直接関係しない事項をいかに省略するかにかかっている。

だから町村氏に期待したいのは、社会地図という主題へ向けて、何が満たされ何が欠け ているかの指摘であった。半ば思いつきの何の工夫もない地図化と、筆者らの一連の仕事 との区別をされているが、〈だがそれだけに〉と言う余りに〈陳腐〉かつ無内容な接続詞で、 あたかも両者が同じ誤りに陥っていると言われるとしたら残念である。内容を明示しない まま一刀両断に断定する快感に酔って、思考を停止されないことを希望したい。

\section{3 クラスター分析の方法をめぐって}

町村氏の指摘の通り、前書を含めて我々の社会地区分析の方法の核をなすのは、クラス 
ター分析である。クラスター分析は、ホルジンガーに始まる、多くの個体をその類似性に 基づいていくつかのグループに分類する一連の統計的手法群を指している。日本の社会科 学分野で、始めてこの方法の意義を認め、具体的には都市分類に適用したのは、安田三郎 である。1959 年のことであった。

クラスター分析は、すべての分析単位と他のすべての分析単位間の相互関係を示す数值 相関係数であったり、距離指標であったりする——についてデータが存在することを 前提として、この数值行列が出発点になる。

町村氏が指摘するように、この場合変数が違えば結果が異なるのは当然である。それは 多くの研究者が先験的に／特定の理論的前提のもとに／しばしば恣意的に、2 基準の組合 せで行う 4 分割表と、原理的にはまったく同じである。変数を変えると、その分類結果が 大きく異なるのは当然である。クラスター分析であるから変数が変われば結果が異なるの ではなく、今あげたようなその研究者が重要と考える 2 変数に基づく分類(a)の場合も、ま た因子分析などのように比較的多くの変数から検出された因子に基づいて分類する場合(b) もまったく同じである。違うのは(a)(b)の場合ほど、我々のクラスター分析の場合は、いく つかの変数が追加、あるいは削除されても、大きくは変化しないことである。(a)の場合 2 変数の一方を変えれば結果は言うまでもなく激変するし、(b)の場合も採用される変数は、 我々の場合のように 30 を越える変数を総合的に考慮することはめったにないからである。

我々の変数採用の基準が一つ一つ明示されていないことに、町村氏の不満が向けられて いるが、データの入手可能性の制約のもとで、意味のあると思われる変数を可能な限りデ 一タファイルに加え、そして地図化をし、我々が何らかの意味を見出すことができた変数 は採用する、これが実際の手続きであった。前述の基層認識のもとでは人口密度、性比、 年少人口比率、青壮年人口比率、老年人口比率などの変数について改めて採用の理由を述 べる必要を感じなかった。そして性比と男性人口比率、老年人口比率と老年人口指数、年 齢標準化出生率と合計特殊出生率のどちらを採用するか、そして年齢と世代の上で重要と 考えて団塊世代比率を採用したなどについては、それぞれ説明している所である。

町村氏のような世界都市論者から見れば重視されるべき F I R E 比率などの変数が含ま れていないことへの、不満があると察せられる。国勢調査には小地区単位の職業／産業小 分類の集計が行われていないなどの理由で、採用することができなかった。職業／産業小 分類は、実はサンプルについてのみ分類のコード付与が行われており、悉皆調査の国勢調 査といいながら、事実上はサンプル調査であって、小地区についてはたとえ原票にさかの ぼることができたとしても集計不能なのである。富裕層の犬散歩させ業のごときは、おも しろい話題としてはありえても、統計的に確認することは不可能なのである。

クラスター分析への疑問の第 2 点として町村氏があげるのは、クラスター併合の打切り 点にかかわる。統計手続ではなく経験的意味をと言われるが、まずは手続き上の処理から 述べねばならない。ホルジンガー＝安田のクラスター分析は、データ行列からもっともb 
係数（そのペアの相関係数ないし距離数值）の高いペアを取り出し、それを一つのクラス ターと認定し、次に $\mathrm{b}$ 係数の高いペア、もしくは既に成立したクラスターに残りの単位を 加入させた場合のもっとも高い $\mathrm{b}$ 係数を示すケースを、新クラスター／改訂クラスターと するという方法で作業を継続し、全単位がいづれかのクラスターに所属した時点で分析 を、終了させるというものであった。コンピュター利用が一般化する前で、このような安 易な処理で満足する他なかったのである。このような幼稚な方法であったため、クラスタ 一分析は、植物分類など常識的な分類の確認に用いられるに止まり、計量的分析の方法と しては副次的な方法と見做されてきたように思われる。

これを大幅に改善したのが、倉沢の KS 法クラスター分析である。ホルジンガー＝安田 の方法では、よりよいクラスター㷌属か否かを判断する基準が、単一のクラスターについ てしか存在しなかった。したがって他のクラスター、いわんや全クラスター・全分析単位 を同時に考慮に入れて最適クラスター㷌属を決定することはとてもできなかったのである が、倉沢の開発したB係数（クラスター分けされた全単位の、同一クラスター内の相関係 数 /距離係数の高さ＝同質性と、異なるクラスター間の相関係数 / 距離係数の低さ＝異質 性から構成）を、全分析単位が適切にクラスター帰属しているかを判断する基準として採 用したことにより、最適クラスター配分が明確な基準により測定されることになった。ホ ルジンガー＝安田の方法は、前述のように全単位、全クラスターへの目配りがなく、結果 として不適当なクラスターへの配分が行われていたのである。この欠点については安田も 認識していたが、コンピューター利用が一般的でなかった時代故、全単位・全クラスター への同時の目配り（演算）は、事実上不可能で、不十分な分析に満足する他なかったので ある。だからクラスター分析の妥当性について町村氏のように踏み込んだコメントを行う のであれば、倉沢のB係数についての評価——積極的な評価であれ批判であれ——が必須 であり、この点の言及がないのは残念である。KS 法クラスター分析と命名したのは、こ のB係数の開発によってクラスター分析そのもののレベルを大きく向上させたという自負 からである。

町村氏の危惧される終結点についても、(1)クラスター併合のすべてのケースを試算し、 B 係数を向上させる組合せが存在しないこと、(2)すべての分析単位のクラスターを、他の すべてのクラスターに所属替えした場合の試算を行い、B係数を向上させるクラスター変 更がこれ以上存在しないことを確認した時点で、分析を停止するのが、KS 法のアルゴリ ズムである。クラスター数を、プログラム内であらかじめ設定することはもちろん可能で あるが、B係数すなわち全単位が最適クラスターに配当されるクラスター分けという分析 目的からして、所与のデータ行列にとって最適のクラスター配当のためには、クラスター 数を限定しない現在の方法が適当と判断している。その数をあらかじめ決めておくこと は、それこそ分析者の染意によって社会的現実を曲げることになるだろう。

町村氏が希望されるのはこの計算手続ではなく、経験的意味ということであるが、上記 
の手続きが最適配分をもたらすことを納得して頂くのが一番であろう。しいて筆者自身に とっての〈実感〉的理由を述べるなら、次の二つの経験がある。一つはこのプログラムを 作成しデバッグする過程で、中間結果を印刷することを繰り返した。単にパッケージ・プ ログラムを利用する場合には接することがあり得ない不可視情報であるが、自作のアルゴ リズムを自らプログラム化する場合には、デバッグのために中間結果の出力が必須であ る。データの一部を用いてプログラムを走らせ、その過程で何が起きているかを繰り返し チェックする作業が延々と続く。ある単位地区を a クラスターに仮に帰属させて試算し、 b クラスターに仮に帰属させて試算しいという無限の段階を一々チェックすることにな る。なぜこの単位がこのクラスターに入るのか、それを所属換えすると他のクラスターに 何が生ずるのかが、常に可視的である。筆者はこの演算過程を単なる機械的過程としてで はなく、意味を伴ったふるい分け——シカゴ流にいえば、 sort and sift の過程として体験 するという、作業的には過酷な、しかし心情的には至福を経験することになった。

一つは、分析にかけられる各単位地区は、人口その他の多次元の指標值を持ち、その值 によって分類されるわけであるが、位置座標は指標值には含まれない。だからコンピュー ターは指標値のみによって各単位地区の類似性ないし近縁性を判断しクラスター分けを行 うのにもかかわらず、取り出されたクラスターは巻頭カラー図（前書、本書とも）に見ら れるように、ある解釈可能な地域的まとまりを示している。23 区でいえば西南の地区の 多くはホワイトカラー住宅地区という共通の色に識別されており、都心部の赤色に塗られ た地区と同じクラスターに属するメッシュが、（75 年の場合）新宿・池袋・渋谷のいわゆ る副都心地区の中央に見られ、そして副都心地区の周縁部と同じクラスターが、規模を小 さくして高円寺・吉祥寺といった地区にも見られることなど、我々の日常的認識とかなり 重なる結果を示している。90 年の場合はこの都心地区が新宿・渋谷と連担して従来の都 心・副都心という常識を覆すという新知見をもたらしている。これらはクラスター分析 が、統計的手続きとして当然に持つことが期待される信頼性だけでなく、空間構造認識の 妥当性を示すと考えるべきではないのか。一種の外的基準ともいえよう。この点に町村氏 が何も触れず、ただ観念的・一般的な疑問を呈しておられるのは残念である。

筆者がクラスター分析に抱く妥当性への信頼は、上記の演算過程の可視性と、位置情報 を入れない分析がもたらす地域的まとまりの解釈可能性の二つで支えられている。後者は 次の第 3 の疑問への回答とも重なる。

町村氏の第 3 の疑問点は、クラスター命名が怨意的に行われているのではないかという 点にある。析出されたクラスターの命名は、基本的には分析者に委ねらている。その妥当 性を確保するために用意したのが、各クラスターがどのような指標とプラスの／マイナス の関連を持つか否かを示した、クラスターの特性表である。両年度の表を呈示していない のは、ほぼ共通の結果が得られたからである。そして命名の妥当性の補完的根拠は、その 地理的な分布からも得られる。 
例えば 75 年の農山漁村地域は 109 あったが、90 年には 55 に減少した。このクラスタ 一から移動したのは大半（44）は半農村地域、そして人口再生産ブルーカラー地域への 印西市他であり、後者については住宅開発その他の理由が明らかであり、前者については その多くが比較的交通の便宜のよい地域であることから、半農村へ移動したと考えられ、 他方 75 年の半農村地域の大多数が同一クラスターに止まっていることから、両者のクラ スター名称はほぼ妥当であり、クラスター継承という表現も不適当とは考えていない。地 場産業地域は入れ替わりの激しいクラスターであったが、もっともこの名称にふさわしい 産業基盤を持つ、羽生・行田・加須・石岡・秩父が両年度とも同じクラスターに属すると いう点から見て、この名称、そして継承という用語が適当と判断したものである。

複合市街地域は 75 年の 63 市区町村から半減している。それは主要には次の 3 つ動 きによる。一つは16の市区町村が人口再生産ホワイトカラー地域へと移行したこと。そ の内容は主に東京都下の西部の市町村おょび神奈川県の東京郊外的な色彩の市区であり、 一面で複合市街地域の成熟ないし結晶化、他面で人口再生産地区の 3 分化という形の結晶 化の結果と判断される。他の一つは、人口再生産工業地域への移動（11）であり、荒川・ 板橋・太田・墨田など 23 区東部南部の工業地区が、他の地区との異質性に基づき、川 崎・横浜の一部の区と共に、このような移動——工業化による結晶化が生じたと考える。

第 3 は、郊外高級住宅地区の析出である。75 年の複合市街地域のなかから、鎌倉・逗 子・大磯・葉山が、75 年人口再生産地域クラスターに含まれていた二宮と共に、新クラ スターとして分離析出された。繰り返せば位置情報を与えていない中で、それぞれの市町 村のデータのみに基づいて、KS 法クラスター分析が、その類似性ないし近縁性を判断し て析出したクラスターである。そして補完的基準である地域的まとまりという基準が有効 に働いた例といってよいであろう。郊外高級住宅地域という名称はここから生まれた。も っといい表現はあるかもしれないが、命名の根拠は明らかであろう。

ちなみにクラスターの命名が、変数との関連から導かれるという点では、因子分析にお ける因子の命名と、まったく同じである。クラスター分析の相対的有利性は、補完基準と して地域的まとまりがあるという点であろうか。そして変数が入れ替えられたり追加され れば、結果はそれに左右される可能性があるという点も、クラスター分析・因子分析にま つたく共通である。因子分析についてこの種の疑問が提出されることはあまりなく、クラ スター分析についてのみ疑問だとされるのは、不可解である。因子分析がパッケージプロ グラムとしてしばしば用いられるという既成パッケージ信仰、ないし「赤信号みんなで渡 れば怖くない」といった心情でなければ幸いである。

東京圏に関する我々の知見は、町村氏を含むすべての読者の批判や別の観点からの分析 に対して開かれている。我々のデータの解釈は、本書のどこかで触れたように、一つの可 能性を示すに過ぎない。特性表や地域的まとまりから見て、各クラスターに異なった視点 からの命名・意味付けをすることを含め、多様な再解釈は自由である。本書がデータの共 
有の上で、東京の空間構造についての議論を広げ、深める助けとなることを願うものであ る。

(くらさわすすむ／放送大学客員教授) 